\title{
Selected macroeconomic determinants and economic growth in Cameroon (1970-2018) "dead or alive" an ARDL approach
}

\author{
Kesuh Jude Thaddeus and Chi Aloysius Ngong \\ Banking and Finance, Faculty of Business Administration, University of Nigeria, \\ Enugu, Nigeria \\ Njimukala Moses Nebong \\ Faculty of Economics and Management Sciences, University of Bamenda, \\ Bambili, Cameroon \\ Akume Daniel Akume \\ Higher Technical Teacher Training College BUEA, University of Buea, \\ Buea, Cameroon \\ Jumbo Urie Eleazar \\ Faculty of Economics and Management Sciences, University of Bamenda, \\ Bambili, Cameroon, and \\ Josaphat Uchechukwu Joe Onwumere \\ Banking and Finance, Faculty of Business Administration, University of Nigeria, \\ Enugu, Nigeria
}

\begin{abstract}
Purpose - The purpose of this paper is to examine key macroeconomic determinants on Cameroon's economic growth from 1970 to 2018.

Design/methodology/approach - Data were obtained from the World Development Indicators and applied on time series data econometric techniques. The auto-regressive distributed lag (ARDL) bounds model analyzed the data since the variables had different order of integration.

Findings - The results showed long and short runs' positive and significant connection between economic growth in Cameroon and government expenditure; trade openness, gross capital formation and exchange rate. Human capital development, foreign aid, money supply, inflation and foreign direct investment negatively and significantly affected economic growth in the short and long-runs. Hence, the macroeconomic indicators are not death.

Research limitations/implications - The present research paper has tried to capture the impact of nine macroeconomic determinants on economic growth such as the government expenditure (LNGOVEXP), human capital development (LNHCD), foreign aids (AID), trade openness (LNTOP), foreign direct investment (LNFDI), gross capital formation (INVEST), broad money (LNM2), official exchange rate (LNEXHRATE) and Inflation (LNINFLA). However, these variables have the tendency to affect each other in a unidirectional or bidirectional manner. Further, the present research paper is unable to capture the impact of other macroeconomic variable due to the unavailability of data.
\end{abstract}

C Kesuh Jude Thaddeus, Chi Aloysius Ngong, Njimukala Moses Nebong, Akume Daniel Akume, Jumbo Urie Eleazar and Josaphat Uchechukwu Joe Onwumere. Published by Emerald Publishing Limited. This article is published under the Creative Commons Attribution (CC BY 4.0) licence. Anyone may reproduce, distribute, translate and create derivative works of this article (for both commercial and noncommercial purposes), subject to full attribution to the original publication and authors. The full terms of this licence may be seen at http://creativecommons.org/licences/by/4.0/legalcode
Economic growth in Cameroon
Received 16 May 2021 Revised 23 June 2021 24 June 2021 10 July 2021 21 August 2021 5 September 2021

7 September 2021

8 September 2021

Accepted 13 September 2021 
Practical implications - The study recommends that Cameroon should use proper planning and strategic policy interventions to achieve higher sustainable economic growth with human capital development, foreign aid, money supply, foreign direct investment and moderate inflation.

Social implications - Macroeconomic indicators, if managed well, increase economic growth.

Originality/value - This paper to the best of the researcher's knowledge presents new background information to both policymakers and researchers on the main macroeconomic determinants using econometric analysis.

Keywords Economic growth, Government expenditure, Trade openness, Gross capital investment, Exchange rate

Paper type Research paper

\section{Introduction}

Economic development and growth have always been central to human society. The topic continues to dominate public debate at the heart of human concern in today's globalized world. Countries with extraordinary growth and development are celebrated as wonders and nicknamed "growth miracles." A major policy challenge confronting Cameroon and African countries is reducing poverty by generating and maintaining higher economic growth rates while maintaining environmental protection (Acemoglu, 2009; Barro et al., 2004; Heshmati et al., 2015; Kim and Heshmati, 2014). Population growth, rapid urbanization, limited urban infrastructure, insufficient facilities, global economic crisis, corruption and inefficiency, and climate change are the problems faced by the African continent (Belshaw and Livingstone, 2002; Binns et al., 2012; Chitonge, 2014; Johnson, 2016; Robson and Lury, 2011).

Therefore, the researcher wants to know if Cameroon's economic growth determinants are reckonable. Macro-economists have been debating this subject for a long time. Any economic strength is perked to empirical test macroeconomic determinants. Cameroon has gone through a diverse number of macroeconomic changes since independence, Country Assistance Evaluation (CAE) (2001). Cameroon has gone through three critical evolutionary periods. The first from 1960 to 1986 marked by real economic growth and the second from 1986 to 1994 marked by economic crisis. Since 1986, Cameroon's macroeconomic indicators have been declining primarily due to the fall in world commodity prices and internal problems. Cameroon's economy major flaws were revealed as budget deficit grew amid several measures taken to curb government spending in order to raise revenue and lower deficits. Cameroon started recovery from the crises in 1995 till date although the recovery does not reflect the Cameroon's economic resources and potential in this globalization era. This study identifies the most effective macroeconomic variables to boost Cameroon's economic growth and development. A quarter century after independence, Cameroon's economy is rated as a lowerincome country. Cameroon was one of Africa's wealthiest nations in natural resources until 1980s, when exports commodity prices for petroleum, cocoa, coffee and cotton declined. This resulted in overvaluation of the currency and economic mismanagement that led to an economic downturn. Between 1986 and 1994, the country's gross domestic product fell by $60 \%$. Its current account deficits, fiscal deficits and foreign debt all increased at a rapid pace. Despite difficult economic situation, Cameroon retains oil reserves and favorable agricultural conditions, making it one of the best in sub-Saharan Africa (SSA).

Disagreement between economists exists about which policies are best for long-term economic development and growth. De Long and Summers (1992) argued that macroeconomic policies are needed for long-term economic growth, while Anderson and Jodon (1968) suggested that monetary policy greatly and rapidly impacts economic growth. Monetary policy measures should be prioritized over fiscal policy. To Uniamikogbo and Enoma (2001), monetary policy indicators are more powerful than fiscal policy interventions in bringing about economic change. Many academics like Barro (1990) argued that human capital development, specifically educational investment and training, contributes to long-run growth. 
Molua (2010) claimed that most SSA economies including Cameroon have inefficient domestic output and trading structures. These inefficiencies result from ineffective government policies that stifle competition and limit economies of scales. To Tambi (1984), Cameroon practiced developmental interventionist approach where exchange rate and interest rate were regulated between 1960 and 1961. The government quantitatively restricted trade and controlled private sector and every economic activity wholly. To combat market uncertainty and price instability, the marketing board was created where farmers register to guarantee their crops and participate in the cash economy by paying the same price for the same product to everybody, regardless of position.

To Molua (2010), macroeconomic imbalances in 1980s negatively affected demand, exchange rate, foreign funding and aggregate production. The country started structural adjustments in 1990s to boost economic growth through macroeconomic stability and budget deficits decrease. Cameroon GDP was growing averagely at $4 \%$ due to improvement on public finances. Despite the hope of emerging from a long economic hardship, Cameroon still has a negative trade balance with trading partners like Spain, Italy, France, the United Kingdom, the United States and the Netherlands. Agriculture, with a 25\% share of GDP is still the economy's backbone. Walters (1966) examined the effect of money supply shifts on UK's gross national product value for 80 -year time series data. The findings showed that with money supply as the primary monetary policy weapon, a $1 \%$ increase in autonomous money supply results to a less than $1 \%$ GDP increase, everything being equal. Aku (2002) tested the Keynesian hypothesis in Nigeria from 1970 to 2000. The findings revealed that money supply has no bearing on the Nigerian situation. The findings revealed that rather than dropping interest rates, increases in money supply increases the overall price levels. Economic researcher like Baye et al. (2002), Tambi et al. (2012), Fambon et al. (2004) and Njinkeu et al. (1997) analyzed Cameroon's microeconomics indicators using poverty, inequality and living standards.

Despite macroeconomic policy interventions in Cameroon, the economy has not performed well relative to growth since 1994 growing at a slow rate. Information in Figure 1 reveals that the Cameroon's annual GDP growth in 1986 was $6 \%$ and decrease to $-2.14 \%,-7.82 \%$, $-1.82 \%,-6.10 \%,-3.80 \%,-3.1 \%$ and $-7.93 \%$ in $1987,1988,1989,1990,1991,1992$ and 1993 , respectively. Then GDP increased from $2.12 \%$ in 1994 to $4.29 \%$ in 1999 . It decreased to $4.23 \%$ in 2002 then increased to $6.7 \%$ in 2006 and decreased to $2.19 \%$ in 2009 before rising to $5.65 \%$ in 2015 . The volatility makes it difficult to ask what macroeconomic factors and policy implications are driving Cameroon's economic growth in the 21st century.

Most studies in Cameroon focus on poverty and growth channels. Limited studies reviewed the macroeconomic indicators affecting Cameroon despite the crucial nature of the information for public policy on poverty eradication. This paper targets the following goals: (1) Examine the main drivers of real economic growth; (2) Establish short and long-term causality between macroeconomic variables and GDP growth; (3) Examine the most important determinants of economic recovery in the globalization era and recommend effective macroeconomic metrics for improving Cameroon's economic development. Since every nation's goal is to improve the living standard of the population through economic growth and development, time series data provides a good analytical context for identifying the main macroeconomic drivers of economic growth. Many governments are still unaware of the core macroeconomic growth metrics and policies that apply to the economies.

\section{Literature review}

\subsection{Theoretical review}

Studying factors that influence economic growth is the central tenets among theoretical and empirical growth researchers with little consensus. Economic growth theory has largely been discussed in academic circles between two major theorists: neoclassical and endogenous 
JBSED

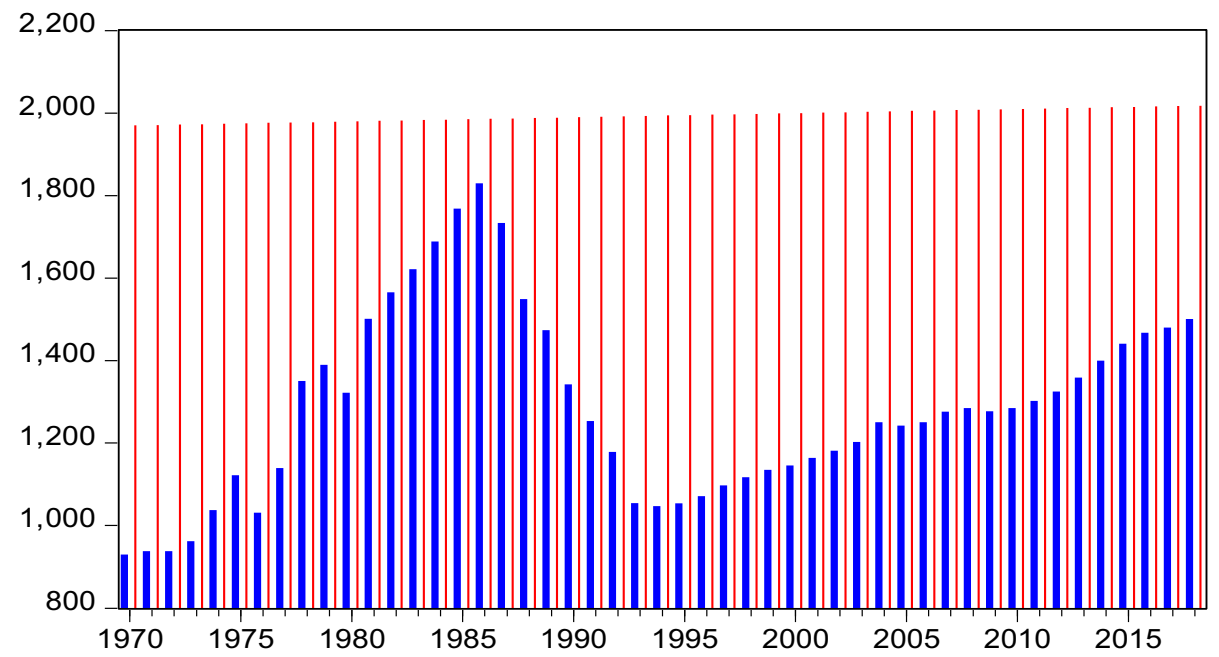

Figure 1.

Source(s): World Bank, 2020

growth theories. Emphasis is on the significance of factors like physical capital accumulation and human capital growth (Solow, 1956; Lucas, 1988). Other economic growth contributors like Easterly et al. (1989) and the World Bank (1990) significantly contributed to growth literature.

Solow-Swan (1956) developed the neoclassical growth theory which is equally called the endogenous growth model. The theory states that physical capital accumulation is a key short-run economic growth driver while technology is the primary determinant of long-run economic growth. The neoclassical theory was expanded to include human capital stock as main driving factors of economic development (Mankiw et al., 1992; Islam, 1995). The endogenous growth theorists contributed mainly with the inclusion of efficiency like learning-by-doing and useful technical skills as critical growth drivers (Lucas, 1988; Grossman and Helpman, 1991; Aghion and Howitt, 1992).

In every country, accumulation of physical capital, human capital stock and productivity factors are important macroeconomic determinants of economic growth (Solow, 1956; Frankel, 1962; Lucas, 1988; Mankiw et al., 1992; Aghion and Howitt, 1991; Grossman and Helpman, 1992). Easterly and Wetzel (1989), World Bank (1990) and Fischer (1992) believed that savings and investment are essential economic growth factors. These factors became popular in 1990s and focus on three main outcomes: macroeconomic stability, efficacy of an economy's institutional system like political and governance, incentive systems, social infrastructure, adequate price mechanism development and regulatory environment to clear markets.

For Fischer (1992), macroeconomic stability is important for economic growth due to the uncertainty in predicting the future economic variables' value. Uncertainty caused by policies is one source of uncertainty because it reduces the market mechanism's ability to react to demand and supply. If inflation, government spending, real exchange rates, real interest rates and population growth rise, this impacts negatively on potential economic growth rates. The second type of uncertainty is temporal uncertainty, which arises when investors hold on to 
their assets until the macroeconomic environment stabilizes. This kind of unpredictability might result in capital flight if not controlled (Pindyck and Somalino, 1993; World Bank, 1990).

Barro and Sala-i-Martin (1992), Mundell (1963), Fischer (1983), Bruno and Easterly (1998), Burnside and Dollar (2000), McKinnon (1973), Shaw (1973), Knight et al. (1993) and Solow (1956), Boserup (1996) modeled government expenditure, inflation, real exchange rate stability, foreign aid, financial development, international trade and population with little consensus on their effect on economic growth.

Many growth economists choose many macroeconomic determinants as possible provided there are enough time series data and degrees of freedom to manage the study (Sala-i-Martin et al., 2004; Ciccone et al., 2010). Many studies support choosing a large number of determinants, arguing that the robustness of determinants is ensured by including more economic growth determinants (Doppelhofer et al., 2004; Bayraktar and Wang, 2006). Contrarily, the approach shows that the variables behave differently when pooled together which may confuse policymakers on country-specific economic policies.

Macroeconomic theory identified various factors that influence a country's growth from the classical, neoclassical and new growth theories. Antwi et al. (2013) asserted that these factors include natural resources, investment, human capital, innovation, technology, economic policies, governmental factors, foreign aid, trade openness, institutional framework, foreign direct investment, political factors, socio-cultural factors, geography, demography and many others. This study considers most of these factors to examine the evidence of the macroeconomic factors on Cameroon's economic growth.

\subsection{Empirical reviews of key macroeconomic determinants and economic growth}

Fischer (1992) compares macroeconomic stability and economic development in SSA and LAC countries from 1970 to 1985 . Human capital, investment and budget surplus were found to be positively and substantially associated with economic growth using a cross-section regression, while initial real GDP, inflation and dummy variables for SSA and LAC were found to be negatively associated with economic growth. This implied that any country's economic growth is supported by a sustainable degree of macroeconomic stability.

Chen and Feng (2000) used panel data to investigate the impact of trade openness, stateowned enterprises, inflation, investment and enrollment in higher education on China's economic development. The findings show that trade openness and university enrollment positively and significantly associated with GDP, whereas inflation and state-owned enterprises negatively and significantly associated with economic growth. Private businesses, foreign trade and education were the key determinants of long-term economic growth.

Knight et al. (1993) used panel regression method to examine macroeconomic variables like human capital, investment, public investment and trade openness on a sample of 81 countries on economic growth. The findings showed a significantly positive relationship between physical capital, human capital development and economic growth while trade openness and population growth negatively and significantly associated with economic growth. Physical capital, human capital development, public investment, trade openness and population growth were key determinants of economic growth. Chang and Mendy (2012) used panel data with fixed effects to examine the relationship between trade openness and economic growth in 36 African countries from 1980 to 2009. The results indicated that foreign assistance, exports, imports, labor employed and trade openness were positively associated with economic growth, while foreign direct investment, domestic investment and gross national savings were negatively associated with economic growth. Foreign aid yielded mixed results by region, foreign assistance had a positive and significant effect on economic 
growth in the Middle and North African regions, with a negative and significant impact on economic growth in the West and East African regions.

Ismaila and Imoughele (2015) investigate the macroeconomic determinants of economic growth in Nigeria using a co-integration approach. The study reveals that Nigeria's economic growth is positively influenced by gross fixed capital formation, total government expenditure and foreign direct investment. Inflation negatively related to economic growth. Hence, macroeconomic stability is enhanced through sound monetary and fiscal policies. Phiri (2013) investigates the relationship between economic growth, foreign direct investment and inflation in Zambia using a threshold auto-regressive (TAR) technique. Inflation is associated with improved economic growth if inflation stays below $22.5 \%$; if inflation rises above this level, inflation negatively impacts on economic growth, whereas foreign direct investment has a positive impact on growth.

Anyanwu (2014) examines the main microeconomic factors affecting economic growth in Africa (1996-2010) and China (1984-2010) using cross-country panel data. Domestic investment, foreign aid, human capital development, metal price index, government effectiveness and urban population positively and significantly impacted economic growth in Africa, while domestic investment and trade openness positively impacted economic growth in China. Credit to the private sector, agricultural rate and urban population negatively impacted economic growth in China. Checherita-Westphal and Rother (2012) explore the relationship between government debt and economic growth in 12 European countries between 1970 and 2008. The findings revealed that government balance, private investment and trade openness had a positive impact on economic growth, while population growth and real interest rates had no effect. Government debt strongly and substantially impacted economic growth. Barro (2003) examined the factors that influenced economic growth in a panel of 87 countries from 1965 to 1995. Human capital production, investment, rule of law, democracy and trade openness positively associated with economic growth, while GDP, life expectancy, fertility rate, government consumption, inflation rate and landlocked negatively associated with economic growth.

Antwi et al. (2013) examined the relationship between macroeconomic determinants and economic growth in Ghana from 1980 to 2010, using co-integration and error correction models. The results revealed that physical infrastructure, foreign direct investment, foreign assistance, inflation and government spending on economic growth have a long-run relationship. Short-term shifts in labor force affect economic development. The ECM coefficient indicates a slow equilibrium change rate. Ullah and Fand Rauf (2013) found a connection between key macroeconomic indicators and economic growth in Asian countries using panel data from 1990 to 2010. The findings show that foreign direct investment and savings rate positively affect economic growth, while exports negatively impact. Economic growth was unaffected by the labor force and tax levels.

Zafar and Zahid (2013) examined key macroeconomic variables effect on economic growth using multiple regression from 1959-1960 to 1996-1997. Primary education is a critical precursor for rapid growth. Increasing the physical capital stock and economy's openness contribute to growth. The findings showed that budget deficit and external debt negatively related to economic growth. This implies that relying on domestic resources is the best option to finance growth and highlight the importance of long-run growth-oriented policies to achieve sustainable growth. Ndambiri et al. (2012) used the generalized system of moments (GMM) method to investigate the determinants of economic growth in 19 SSA countries from 1982 to 2000. Physical capital development, the export market and human capital formation substantially affect economic growth. Government spending, nominal discount rate and foreign aid negatively affect economic growth. Biswas and Saha (2014) investigate the determinants of economic growth in India using time series analysis from 1980 to 2011. The findings revealed that gross domestic capital formation has a positive impact on GDP in 
the short run. Exports, money supply and foreign direct investment boost growth while inflation and fiscal deficits negatively impact. India experienced stable economic growth during the study period as a result of careful and purposeful management of macroeconomic growth determinants.

Economic growth in Cameroon

\section{Data and methodology}

This study used time series data from World Development Indicators database for Cameroon. This paper examines the key macroeconomic indicators on Cameroon's economic growth and establishes the short- and long-run causal effect. The auto-regressive distributed lag (ARDL) is used to examine the key macroeconomic indicators affecting economic growth in Cameroon. In comparison to traditional co-integration approaches of full maximum likelihood (Johansen and Juselius, 1990) and the residual-based method (Engle and Granger, 1987), the ARDL bounds test approach has some key distinctive features; (1) the ARDL approach used ordinary least square (OLS) for estimating co-integration relationship which is done by selecting respective lag order from the model considered, (2) this technique is found to be statistically significant for all types of variables with $I(1), I(0)$ or jointly integrated (3) the ARDL model tracks the long-run relationship with dependent variables (Shrestha and Chowdhury, 2007). The error correction model (ECM) without dropping the long-run evidence assimilates the short run with long run (Collier and Goderis, 2012). The variables for macroeconomic indicators and economic growth were chosen based on data availability for the period 1970-2018 using annual data.

\section{Model specification}

The classical, neoclassical and modern growth theories established the factors that influence economic growth like natural resources, institutional structure, foreign direct investment, investment, human capital, innovation, technology, economic policies, governmental factors, foreign aid, trade openness, political factors, socio-cultural factors, geography, demography to be some of the important macroeconomic determinants (Antwi et al., 2013). The model specification for economic growth and macroeconomic indicators is given as follows:

GDP $=$ MEI(GOVEXP, HCD, AIDS, TOP, FDI, INVEST, M2, EXCHRATE, INFLA).

Hence, the econometric model is specified as:

$$
\begin{aligned}
\mathrm{LNGDP}_{=} & \beta_{0}+\beta_{1} \mathrm{LNGOVEXP}_{i t}+\beta_{2} \mathrm{LNHCD}_{i t}+\beta_{3} \mathrm{LNAIDS}_{i t}+\beta_{4} \mathrm{LNTOP}_{i t}+\beta_{5} \mathrm{LNFDI}_{i t} \\
& +\beta_{6} \mathrm{LNINVEST}_{i t}+\beta_{7} \mathrm{LNM}_{i t}+\beta_{8} \mathrm{LNEXCHRATE}_{i t}+\beta_{9} \mathrm{LNINFLA}_{i t}+\varepsilon t_{i t} .
\end{aligned}
$$

where,

Dependent Variables

$\mathrm{GDP}_{i t}=\mathrm{GDP}_{i t}$ per capita (current us $\$$ ) ... for Eqn (1).

Explanatory Variables

GOVEXP $_{i t}=$ General government expenditure ( $\%$ of GDP) of country $i$ at time $t$.

$\mathrm{HCD}_{i t}=$ Human capital development measured by school enrollment in secondary school (\% of gross) of country $i$ at time $t$.

$\mathrm{AIDS}_{i t}=$ Net official development assistance and official aid received (constant 2015 US\$) of country $i$ at time $t$. 
$\mathrm{TOP}_{i t}=$ Trade Openness (ratio of import plus exports to $\%$ of GDP) of country $i$ at time $t$.

$\mathrm{FDI}_{i t}=$ Foreign direct investment ( $\%$ of GDP) of country $i$ at time $t$.

$\operatorname{INVEST}_{i t}=$ Gross capital formation ( $\%$ of GDP) of country $i$ at time $t$.

$\mathrm{M} 2_{i t}=$ Broad money ( $\%$ of GDP) of country $i$ at time $t$.

EXCHRATE $_{i t}=$ Exchange rate (period average) of country $i$ at time $t$.

$\mathrm{INFLA}_{i t}=$ Inflation, consumer prices (annual \%) of country $i$ at time $t$.

\section{Discussion of results}

\subsection{Descriptive statistics of selected variables}

Table 1 shows that gross domestic product per capita has an average value of 1296.711 with a standard deviation of 224.2547 and having a maximum value of 1829.195 and a minimum value of 938.0023. The gross domestic product per capita shows that the GDP fluctuated over the years of study. Government expenditure has an average value of $11.07488 \%$ and a standard error of $1.124151 \%$ ranging from 13.27465 maximum to 8.837744 minimum values. Human capital development has an average value of $27.20552 \%$ and a standard error of $13.42664 \%$ ranging from 60.05816 maximum to 8.170410 minimum values. Official development assistance and official aid received has an average value of $6.33 \mathrm{E}+08$ and a standard error of $3.22 \mathrm{E}+08$ ranging from $1.82 \mathrm{E}+09$ maximum and $2.50 \mathrm{E}+08$ minimum values. Trade openness has a mean of 49.19386 and a standard error of 8.012908 with a maximum value of 65.02459 and a minimum value of 31.99461 . Foreign direct investment has an average value of 2.457352 and a standard error of 3.935537 ranging from 19.03948 maximum to 0.001202 minimum values. Gross capital formation has an average value of 22.05241 and a standard error of 3.551837 ranging from 31.24881 maximum to 14.30539 minimum values. Broad money has an average value of 18.16671 and a standard error of 3.394053 ranging from 23.66621 maximum and 11.66045 minimum values. Official exchange rate has an average value of 418.0199 and a standard error of 155.3980 ranging from 732.3977 maximum to 211.2796 minimum values. Inflation has an average value of 87.53682 and a standard error of 195.3013 ranging from 1231.621 maximum and 0.000258 minimum values.

Furthermore the descriptive statistics revealed that, GDP, HCD, AIDS, FDI, INVEST, EXCHRATE and INFLA were positively skewed meaning that, their mean are peaked to the right of the distribution while GOVEXP, TOP and M2 were negatively skewed meaning that their mean were peaked to the left.

The kurtosis coefficients of GDP, GOVEXP, TOP, M2 and EXCHRATE were below 3.000, showing that they are platokurtic which means they have less extreme outliers than the normal distribution. The kurtosis coefficient of HCD, AIDS, FDI, INVEST and INFLA are above 3.000, meaning that they are leptokurtic relative to the normal, meaning that their distribution produces more extreme outliers than the mesokurtic distribution.

The Jarque-Bera probability statistics for GDP, GOVEXP, TOP, INVEST; M2 and EXCHRATE are normally distributed because their probability values is above $5 \%$ while HCD, AID, FDI and INFLA are not normally distributed since the probability value is less than $5 \%$. The descriptive statistics above was done with the raw data.

Human capital development, foreign aids, trade openness, foreign direct investment, gross capital formation, broad money, official exchange rate and inflation are positively correlated to economic growth while government expenditure presents negatively correlate to GDP. According to Gujarati (2004) when the coefficients between the variables exist within certain thresholds, it signals weak, moderate and strong correlation in positive or negative directions. 


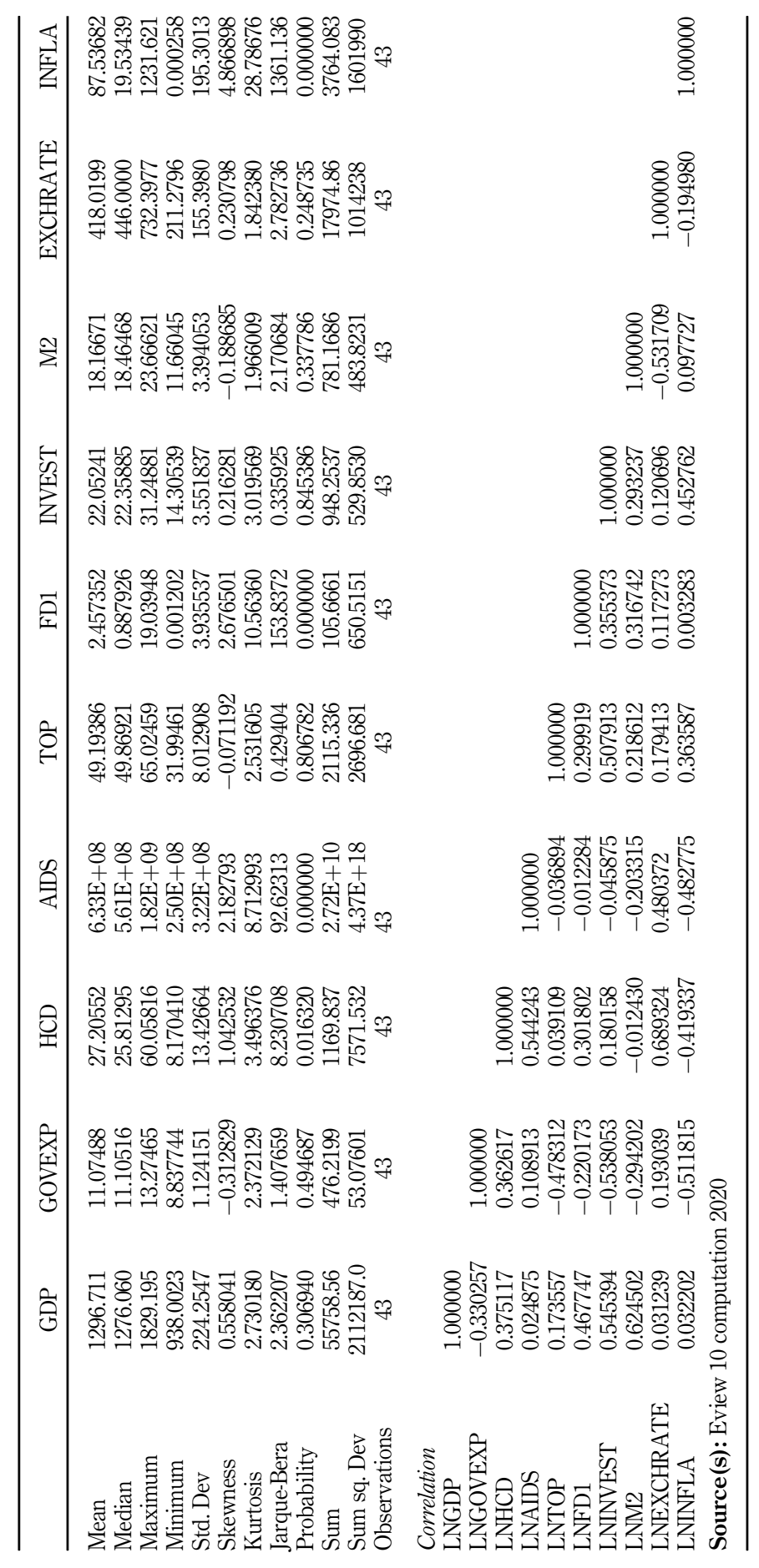

Economic growth in Cameroon 
If the coefficients lie below 0.5(-0.5), it is weak correlation like human capital development, foreign aids trade openness, foreign direct investment, official exchange rate and inflation, when it is between $0.5(-0.5)$ and $0.8(-0.8)$, it is moderate correlation like gross capital formation, broad money and if it is above $0.8(-0.8)$, indicates strong multicollinearity. From the correlation section, the presence of multicollinearity can be inferred. Since the correlation coefficients presented only scenario of weak and moderate across all the variables.

\subsection{Stationarity test and bound test results}

Table 2 shows the stationarity properties of variables using the Augmented Dickey-Fuller (1979) and Phillips-Perron (1988). Some variables were stationary at level I(0), while others difference I(1). Gujarati (2003) proposed the ARDL approach to co-integration to determine how dependent variables react to changes in independent variables in the long and short runs. This approach by Pesaran and Shin (1999) has many advantages over the Johansen co-integration approach. It is used whether the data are strictly $\mathrm{I}(0)$, purely $\mathrm{I}(1)$ or mixed integrated. The official exchange rate, broad money, trade openness, government expenditure are stationary at first difference while gross domestic product, human capital development, inflation, foreign aid and gross capital formation are stationary at level, thus bounds checks is used to investigate a co-integration relationship (Pesaran et al., 2001).

The bound test shows that at $1 \%$ and $5 \%$ significance levels, the $F$-statistics is 10.22115 , higher than the lower bound of 2.5 at $1 \%$ and 2.04 at $5 \%$ significance level as well as the upper bound of 3.68 at $1 \%$ and 2.08 at $5 \%$ significance level. The results reject the null hypothesis of no co-integration. A long-run co-integration exists between macroeconomic indicators and economic growth. The effect of key macroeconomic indicators on Cameroon's economic growth is investigated using a long-run estimation test as shown in Table 3.

\subsection{ARDL long-run coefficients}

In Table 3 above, the $R^{2}$ value is 0.997539 with the modified $R^{2}$ value being $0.988,045$, implying that the independent variables account for $99.7 \%$ of variations in Cameroon's economic development. This demonstrates that the model substantially explains the variation in Cameroon's economic growth with a good match. The null hypothesis is rejected because the $F$-statistics (105.0748) indicates the model's overall importance at $1 \%$ level because the likelihood value $(0.000001)$ is below 0.05 critical values. The Dublin Watson statistic (2.576619) is within the appropriate bound, indicating no serial autocorrelation.

The lag value of per capita GDP growth is integrated into the model to capture previous years' effects. At the $1 \%$ significance level, a $1 \%$ rise in the previous year's GDP growth rate results in a $71 \%$ increase in the current year's GDP growth rate. Government expenditure, trade openness, exchange rate and gross capital formation showed a long-run positive significant effect on the GDP at a 1\% level and 10\% but exhibit a negative effect on the first lag and a positive effect on the second lag. This implies the effect of government expenditure, trade openness exchange rate and gross capital formation are positively on Cameroon's economy only after the second lag at a significant level of $1 \%$ hence a $1 \%$ increase in government expenditure, trade openness, exchange rate and investment lead to an increase of $46 \%, 43 \%, 46 \%$ and $44 \%$ in GDP, respectively. The results are in line with the work of Checherita-Westphal and Rother (2012) and Barro (2003). The positive relationship between government spending and economic growth suggests that government spending will help mobilize idle capital, resulting in increased long-term economic growth. The positive relationship between trade openness and economic growth indicates that Cameroon's government supports more exports than imports, resulting in long-term economic growth. A positive relationship exists between exchange rate and economic development. This implies that Cameroon enjoyed a stable rate of currency exchange with other currencies which 


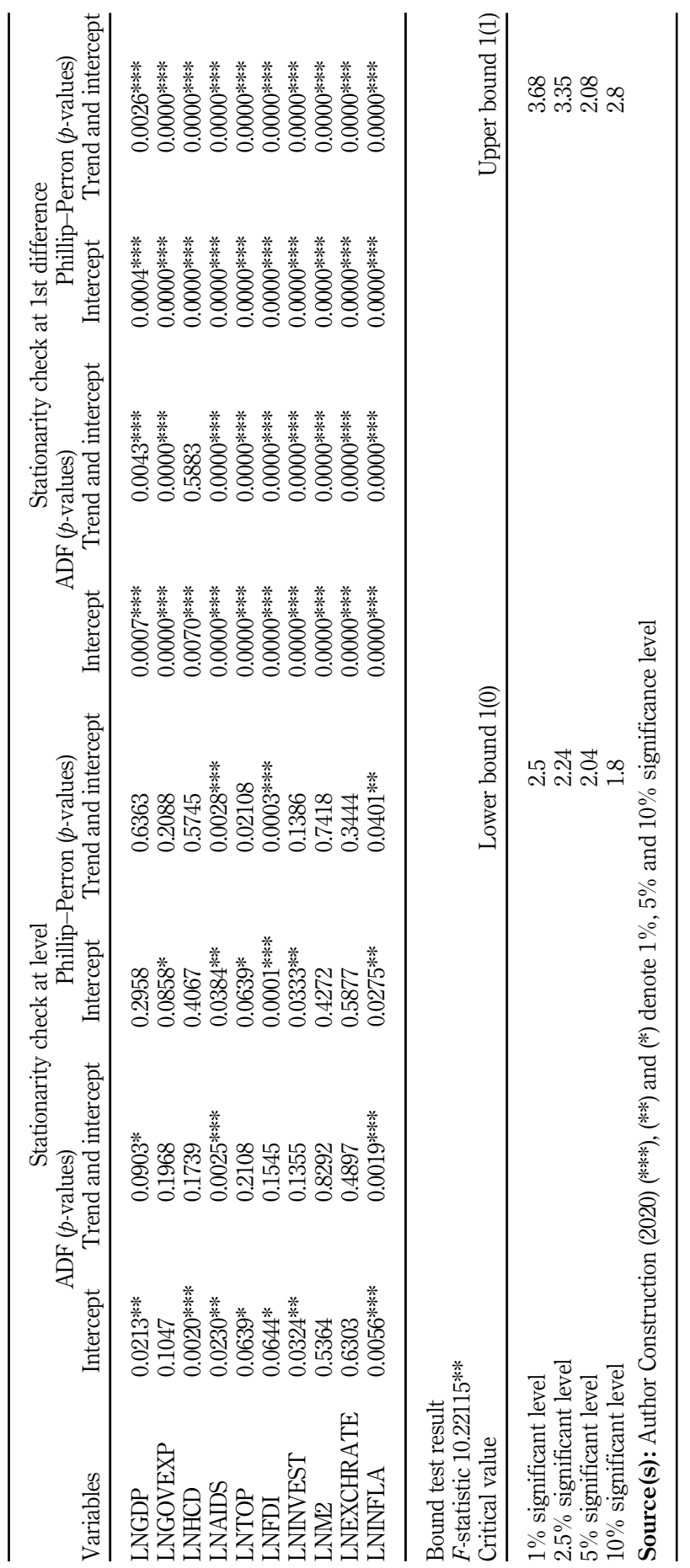

Economic growth in Cameroon

Table 2. Stationarity test and bound test results 
Dependent variable: LNGDP

Dynamic regressors (2 lags, automatic): LNGOVEXP LNHCD LNAIDS

LNTOP LNFD1 LNINVEST LNM2 LNEXCHRATE LNINFLA

Selected model: ARDL(1, 2, 2, 1, 2, 2, 2, 2, 2, 2)

\begin{tabular}{|c|c|c|c|c|}
\hline Variable & Coefficient & Std. Error & $t$-statistic & Prob* \\
\hline LNGDP(-1) & 0.710297 & 0.169731 & 4.184828 & 0.0041 \\
\hline LNGOVEXP & 0.460555 & 0.214978 & 2.142340 & 0.0694 \\
\hline LNGOVEXP(-1) & -0.922897 & 0.181782 & -5.076953 & 0.0014 \\
\hline LNGOVEXP(-2) & 0.772735 & 0.138817 & 5.566589 & 0.0008 \\
\hline LNHCD & -0.609411 & 0.167837 & -3.630970 & 0.0084 \\
\hline $\mathrm{LNHCD}(-1)$ & 0.382466 & 0.084881 & 4.505884 & 0.0028 \\
\hline $\mathrm{LNHCD}(-2)$ & 0.283407 & 0.156721 & 1.808360 & 0.1135 \\
\hline LNAID & -0.075715 & 0.020575 & -3.680047 & 0.0079 \\
\hline LNAIDS(-1) & 0.064842 & 0.026425 & 2.453789 & 0.0439 \\
\hline LNTOP & 0.430851 & 0.103707 & 4.154510 & 0.0043 \\
\hline LNTOP(-1) & -0.464493 & 0.119358 & -3.891597 & 0.0060 \\
\hline LNTOP(-2) & 0.133029 & 0.052513 & 2.533230 & 0.0390 \\
\hline LNFD1 & -0.011809 & 0.004650 & -2.539374 & 0.0387 \\
\hline LNFD1(-1) & -0.025796 & 0.005847 & -4.411883 & 0.0031 \\
\hline LNFD1(-2) & -0.014175 & 0.005126 & -2.765476 & 0.0279 \\
\hline LNINVEST & 0.463569 & 0.087875 & 5.275304 & 0.0012 \\
\hline LNINVEST(-1) & -0.474255 & 0.084031 & -5.643836 & 0.0008 \\
\hline LNINVEST(-2) & 0.275403 & 0.059448 & 4.632657 & 0.0024 \\
\hline LNM2 & -0.672165 & 0.132760 & -5.063024 & 0.0015 \\
\hline LNM2(-1) & 0.609784 & 0.090353 & 6.748912 & 0.0003 \\
\hline LNM2(-2) & 0.332649 & 0.166856 & 1.993628 & 0.0864 \\
\hline LNEXCHRATE & 0.440642 & 0.105665 & 4.170159 & 0.0042 \\
\hline LNEXCHRATE(-1) & -0.686060 & 0.141908 & -4.834537 & 0.0019 \\
\hline LNEXCHRATE(-2) & 0.346896 & 0.104469 & 3.320548 & 0.0128 \\
\hline LNINFLA & -0.014703 & 0.004680 & -3.141429 & 0.0163 \\
\hline LNINFLA(-1) & 0.046808 & 0.008020 & 5.836762 & 0.0006 \\
\hline LNINFLA(-2) & -0.006354 & 0.005203 & -1.221151 & 0.2616 \\
\hline$C$ & -1.220519 & & -0.545641 & 0.6023 \\
\hline$R^{2}$ & 0.997539 & \multicolumn{2}{|l|}{ Adjusted $R^{2}$} & 0.988045 \\
\hline$F$-statistic & 105.0748 & \multicolumn{2}{|c|}{$\operatorname{Prob}(F$-statistic $)$} & 0.000001 \\
\hline Durbin-Watson stat & 2.576619 & \multicolumn{2}{|c|}{ Akaike info criterion } & -5.283161 \\
\hline Schwarz criterion & -4.038882 & \multicolumn{2}{|c|}{ Hannan-Quinn criterion } & -4.853636 \\
\hline
\end{tabular}

Table 3.

Schwarz criterion

$-4.038882$

Source(s): Author Construction (2020)

increase economic growth. Investment and economic growth have a positive relationship implying Cameroon's political and economic environment attract capital investments which influences long-term economic growth.

Foreign direct investment negatively and significantly affects economic growth across the current year first lag and second lags in the long run. This implies a $1 \%$ increase in FDI decreases economic growth by $-1.1 \%$ in the current year, $-2.57 \%$ in the first lag and $-1.4 \%$ in the second lag. The negative sign indicates that Cameroon still lacks the "absorptive potential," like structured financial sector, trained labor force and infrastructural factors. This result is worrying given the type and attention Cameroon's government employs to attract FDI. The results are consistent with Chang and Mendy (2012) but defy economic growth theory and expectations.

Broad money, human capital development and Foreign aids negatively affect economic growth in the current year, but positively affect growth in the first and second lags. The indicators' long-term impact on economic growth is felt after the first and second year's 
indicators' injection at $1 \%$ and $5 \%$ levels. The findings contradict economic theory but support the findings of Ndambiri et al. (2012).

Inflation negatively and significantly impacted economic growth. This implies a $1 \%$ inflation rise produces a $1.4 \%$ economic growth drop. The results meet theoretical expectation. Inflation creates price uncertainty for goods and services thus lower inflation increases attracts investors confidence towards investing. An inflation year lag positively impacted economic growth implying a normal level to promote Cameroon's economic growth. The results agrees with that of Fischer (1992), Biswas and Saha (2014), Chen and Feng (2000).
Economic growth in Cameroon

\subsection{ARDL error correction regression estimated short-run coefficients}

Table 4 indicates the short-run relationship using an ARDL model. The ECM results of short run indicate that all the macroeconomics determinants have a significant influence on GDP growth in the short run. The immediate effect of human capital development, foreign aid, money supply, inflation and foreign direct investment on economic growth has remain deflationary in the short run while government consumption expenditure, trade openness, investment and exchange rate affects economic growth positively and significantly in the short run. In the short term, the ARDL results indicate that in order for Cameroon to achieve positive and meaningful economic growth, the contribution of human capital development,

\begin{tabular}{|c|c|c|c|c|}
\hline \multicolumn{5}{|c|}{$\begin{array}{l}\text { Dependent variable: D(LNGDP) } \\
\text { Selected model: ARDL(1, 2, 2, 1, 2, 2, 2, 2, 2, 2) } \\
\text { Case 2: Restricted constant and no trend }\end{array}$} \\
\hline D(LNGOVEXP) & 0.460555 & 0.062830 & 7.330228 & $0.0002^{* * * *}$ \\
\hline D(LNGOVEXP(-1)) & -0.772735 & 0.051263 & -15.07388 & $0.0000 * * *$ \\
\hline $\mathrm{D}(\mathrm{LNHCD})$ & -0.609411 & 0.044793 & -13.60505 & $0.0000 * * *$ \\
\hline $\mathrm{D}(\mathrm{LNHCD}(-1))$ & -0.283407 & 0.037832 & -7.491217 & $0.0001 * * *$ \\
\hline D(LNAIDS) & -0.075715 & 0.007599 & -9.963248 & $0.0000 * * *$ \\
\hline D(LNTOP) & 0.430851 & 0.042374 & 10.16793 & $0.0000 * * *$ \\
\hline D(LNTOP(-1)) & -0.133029 & 0.024411 & -5.449512 & $0.0010^{* * * *}$ \\
\hline D(LNFDI) & -0.011809 & 0.001524 & -7.749262 & $0.0001^{* * * *}$ \\
\hline D(LNFDI $(-1))$ & 0.014175 & 0.001499 & 9.453678 & $0.0000 * * *$ \\
\hline D(LNINVEST) & 0.463569 & 0.031118 & 14.89710 & $0.0000 * * *$ \\
\hline D(LNINVEST(-1)) & -0.275403 & 0.027371 & -10.06195 & $0.0000 * * *$ \\
\hline D(LNM2) & -0.672165 & 0.048661 & -13.81331 & $0.0000^{* * * *}$ \\
\hline D(LNM2(-1)) & -0.332649 & 0.055055 & -6.042071 & $0.0005^{* * * *}$ \\
\hline D(LNEXCHRATE) & 0.440642 & 0.033998 & 12.96062 & $0.0000^{* * * *}$ \\
\hline D(LNEXCHRATE(-1)) & -0.346896 & 0.037402 & -9.274717 & $0.0000^{* * * *}$ \\
\hline D(LNINFLA) & -0.014703 & 0.001686 & -8.721322 & $0.0001^{* * * *}$ \\
\hline D(LNINFLA(-1)) & 0.006354 & 0.001794 & 3.542178 & $0.0094 * * *$ \\
\hline $\operatorname{ECM}(-1)^{*}$ & -0.289703 & 0.017532 & -16.52425 & $0.0000^{* * * *}$ \\
\hline$R^{2}$ & 0.982626 & Adjusted $R$ & & 0.965252 \\
\hline Adjusted $R^{2}$ & 0.965252 & S.D. Depen & & 0.059628 \\
\hline Durbin-Watson stat & 2.576619 & & & \\
\hline
\end{tabular}

\begin{tabular}{lccl}
$\begin{array}{l}\text { Diagnostic test } \\
\text { Test statistics }\end{array}$ & $F$-statistics & $p$-value & Interpretation \\
\hline Heteroskedasticity test: Breusch-Pagan-Godfrey & 0.656476 & $0.7983^{* *}$ & No heteroskedasticity \\
Jacque-Bera test & 0.041672 & $0.9793^{* * *}$ & Normal distribution \\
Ramsey RESET stability & 0.621856 & $0.5739^{* *}$ & Model correctly specified
\end{tabular}

Source(s): Author Construction (2020), (***), (**) and $\left(^{*}\right)$ denote 1\%,5\% and 10\% significance level

Table 4. Short-run ARDL test 
foreign assistance, money supply and foreign direct investment must be improved. This can only happen if the government of Cameroon lay down stimulating and robust economic policy that takes in to consideration changes on the domestic and international front in advance.

The adjustment speed to equilibrium (ECM) when there is a shock from last period's equilibrium error is corrected for in the current period is negative at a $1 \%$ level of significant hence confirming the long-run stability of the model. The ECM is $(-0.289703)$ implying that the speed of adjustment to long-run equilibrium is approximately $29 \%$ annually. Therefore the outcome of the short run suggest that government consumption expenditure, trade openness, investment and exchange rate influences economic growth positively and significantly while human capital development, foreign aid, money supply, inflation and foreign direct investment leads to economic slowdown.

Diagnostic test for serial autocorrelation, heteroskedasticity and normality test of the residual are undertaken for model's robustness. The Breusch-Pagan-Godfrey correlation test, Breusch-Pagan-Godfrey heteroskedasticity test, Jacque-Bera normality test and Ramsey RESET test were used. The results show that the model accepts the null hypothesis of no autocorrelation, homoscedasticity and normal distribution. The relationship between the dependent and independent variables is correctly defined as the $p$-values are greater than $5 \%$ significance level. The CUSUM and CUMSUMQ tests results in Figure 2 reveal that all the parameters exhibit long-run stability at the $5 \%$ significance level.

\section{Conclusion and policy implications}

This study examined key macroeconomic determinants on Cameroon's economic growth in the long and short term from 1970 to 2018. The unit root tests checked the stationary properties of variables. The variables had different integration order hence the bound test and ARDL approach estimated the model. Government expenditure, human capital development, foreign aid, trade openness, foreign direct investment, gross capital formation, money supply, exchange rate and inflation were regressed on economic growth. The results indicate that the determinants have short and long-runs influence on GDP growth.

The findings show significantly positive relationship between economic growth and government expenditure, trade openness, gross capital formation and exchange rate in the long and short runs. A significantly negative relationship exists between economic growth and human capital development, foreign aid and money supply in the short and long run. The main macroeconomic determinants positively or negatively affect Cameroon's long and short-term economic development. The long and short-runs results show that government spending, trade openness, gross capital formation and the exchange rate are the most significant and powerful determinants of Cameroon's economic growth. Proper use of government spending, trade openness, gross capital formation and the exchange rate would promote economic growth. Unlike human capital development, foreign aid, money supply, inflation and foreign direct investment showed a significantly negative effect. The Cameroon government can ignite the indicators for an effective economy with broad base economic policy. The human development expenditure should be transformed to a revenue model.

The government should strengthen the educational system by introducing technical courses in secondary schools and mobilize idle capital into long-term economic development. Government should encourage broad money supply with caution to significantly improve economic growth by decreasing inflation, structural rigidity and corruption. The government should create a favorable investment environment using investment attractive policies and laws. The Cameroonian government's foreign direct investment economic policies have positive spillover effects like technology transfer, skills and know-how, domestic production enhancement, production costs reduction, management performance improvement, mergers and acquisitions competitiveness, domestic investments reorganization and infrastructural 


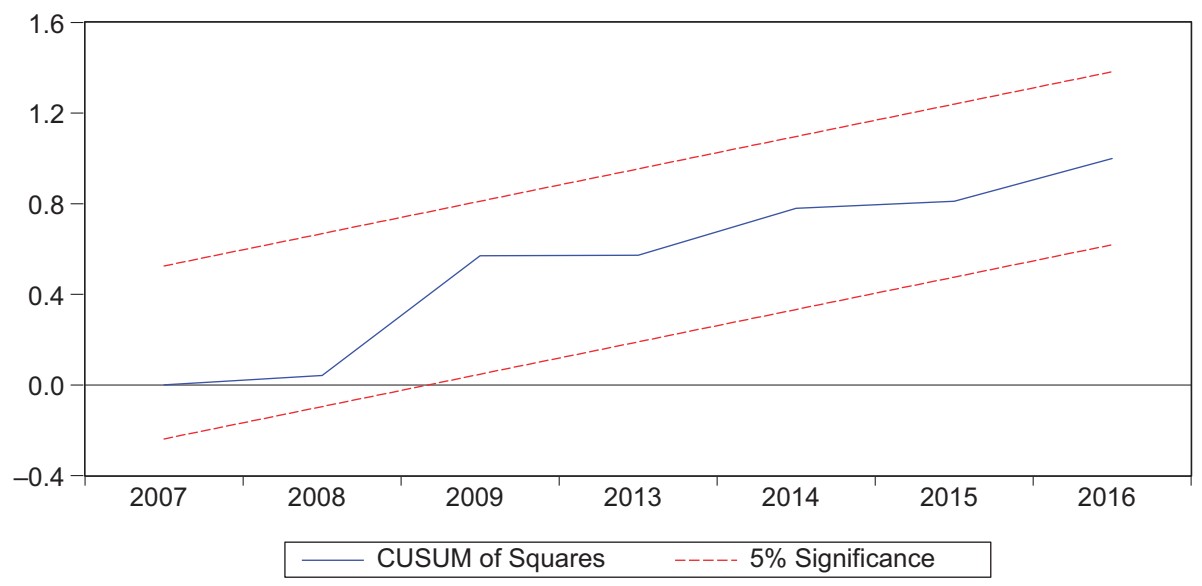

Economic growth in Cameroon

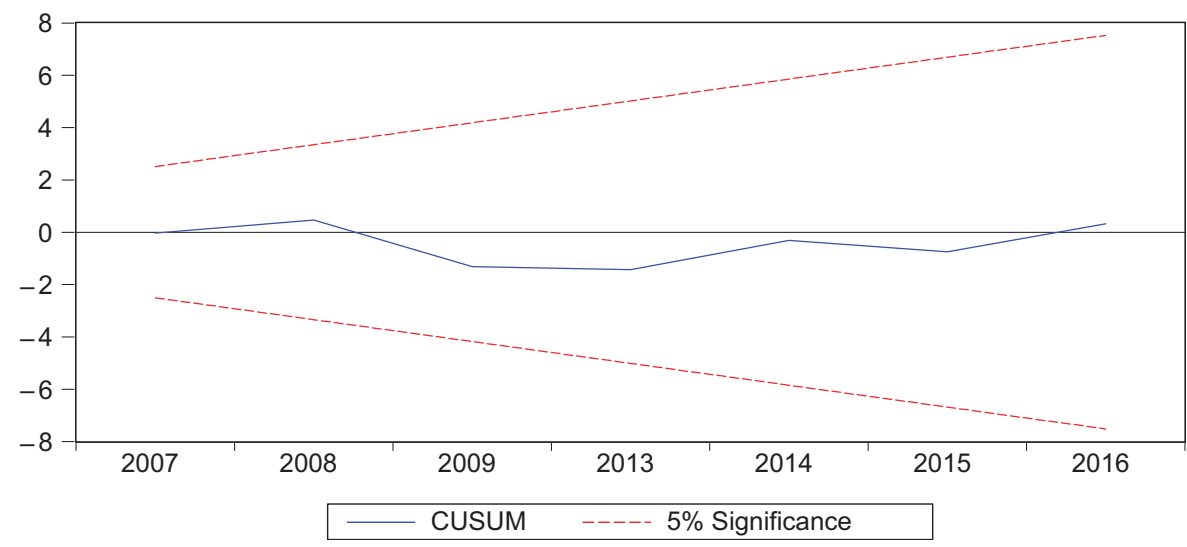

Figure 2.

Graphical representation of cumulative sum of square recursive residual (CUSUM) and cumulative sum of recursive residual (CUSUM)

development. Wholly, all of the considered macroeconomic factors have strong positive and negative impacts on Cameroon's economic development. This indicates that Cameroon macroeconomic indicators are alive. The variables positively impact Cameroon's economic growth when the government implements policies that activates and sustain economic growth.

\section{Limitations of the study and future research}

This paper captures the impact of macroeconomic determinants on economic growth. However, the variables affect each other unit directionally or bi-directionally. The paper is unable to capture the impact of other macroeconomic variables due to data unavailability. The findings suggest researchers should evaluate macroeconomic factors independently in the future to determine the direction of skewness.

\section{References}

Acemoglu, D. (2009), Introduction to Modern Economic Growth, Princeton University Press, New Jersey, NY. 
Aghion, P. and Howitt, P. (1991), "Growth and unemployment", The Review of Economic Studies, Vol. 61 No. 3, pp. 477-494, (July, 1994).

Aghion, P. and Howitt, P. (1992), "A model of growth through creative destruction", Econometrica, Vol. 60 No. 2, pp. 323-351.

Aku, P.S. (2002), "Money supply, interest rate and economic growth in Nigeria", Nigerian Journal of Social and Development Issues, Vol. 2 No. 1, pp. 157-171.

Anderson, L.C. and Jordan, J.L. (1968), "Monetary and fiscal action: a test of their relative importance in economic stabilization", Monthly Review, Federal Reserve Bank of St. Louis, Vol. 50 Novembrt, pp. 11-23.

Antwi, S., Mills, E.F. and Zhao, X. (2013), "Impact of macroeconomic factors on economic growth in Ghana: a cointegration analysis", International Journal of Academic Research in Accounting, Finance and Management Sciences, Vol. 3 No. 1, pp. 35-45.

Anyanwu, J.C. (2014), "Factors affecting economic growth in Africa: are there any lessons from China?", African Development Review, Vol. 26 No. 3, pp. 468-493.

Barro, R.J. (1990), "Government spending in a simple model of endogenous growth", Journal of Political Economy, Vol. 98 No. 5, pp. S103-S125.

Barro, R.J. (2003), "Determinants of economic growth in a panel of countries", Annals of Economics and Finance, Vol. 4, pp. 231-274.

Barro, R.J. and Sala-i-Martin, X. (1992), "Public finance in models of economic growth", The Review of Economic, Vol. 59 No. 4, pp. 645-661.

Barro, R.J. and Sala-i-Martin, X. (2004), "Determinants of economic growth in a panel of countries", Annals of Economics and Finance, Vol. 4, pp. 231-274.

Bayraktar, N. and Wang, Y. (2006), "Banking sector openness and economic growth", Policy Research Working Paper, No. 4019, WorldBank, Washington, DC, OWorldBank, available at: https:// openknowledge.worldbank.org/handle/10986/9273 License: CC BY 3.0 IGO.

Belshaw and Livingstone (2002), Renewing Development in Sub-Saharan Africa Policy, Performance and Prospects, Routledge, London, Vol. 1, p. 496, ISSN 9780415252188 (accessed 6 December 2001).

Binns, T., Dixon, A. and Nel, E. (2012), Africa: Diversity and Development, Routledge, London.

Biswas, S. and Saha, A.K. (2014), "Macroeconomic determinants of economic growth in India: a time series analysis", SOP Transaction on Economic Research, Vol. 1, No. 2.

Boserup, E. (1996), "Development Theory: an analytical framework and selected application", Population and Development Review, Vol. 22 No. 3, pp. 505-515.

Bruno, M. and Easterly, W. (1998), "Inflation crises and long- run growth", Journal of Monetary Economics, Vol. 41, pp. 3-26.

Burnside, C. and Dollar, D. (2000), "Aid, policies, and growth", The American Economic Review, Vol. 90 No. 4, pp. 847-868.

CAE (2001), Cameroon, Country Assistance Evaluation, The World Bank, Washington DC

Chang, C. and Mendy, M. (2012), "Economic growth and openness in Africa: what is the empirical relationship?", Applied Economics Letters, Vol. 19 No. 18, pp. 1903-1907.

Checherita-Westphal, C. and Rother, P. (2012), "The impact of high government debt on economic growth and its channels: an empirical investigation for the Euro area”, European Economic Review, Vol. 56 No. 7, pp. 1392-1405.

Chen, B. and Feng, Y. (2000), "Determinants of economic growth in China: private enterprise, education, and openness. India: a time series analysis. SOP transaction on economic research", China Economic Review, Vol. 11 No. 1, pp. 1-15.

Chitonge, H. (2014), Economic Growth and Development in Africa: Understanding Trends and Prospects, Routledge, London. 
Ciccone, A. and Jarocinski, M. (2010), "Determinants of Economic Growth: will data tell?", American Economic Journal: Macroeconomics, Vol. 2 No. 4, pp. 222-246.

Collier, P. and Goderis, B. (2012), "Commodity prices and growth: an empirical investigation", European Economic Review, Vol. 56 No. 6, pp. 1241-1260.

De Long and Summers (1992), "Equipment investment and economic growth: how strong is the nexus?", Brookings Papers on Economic Activity, Vol. 23 No. 2, pp. 157-212.

Dickey-Fuller (1979), "Distribution of the estimators for autoregressive time series with a unit root", Journal of the American Statistical Association, Vol. 74 No. 366, pp. 427-431.

Doppelhofer, G., Miller, R.I. and Sala-i-Martin, X. (2004), "Determinants of long-term growth: a bayesian averaging of classical estimates (bace) approach”, OECD Economics Department Working Papers 266, OECD Publishing.

Easterly, W.R., and Wetzel, D.L.(1989). "Policy determinants of growth: survey of theory and evidence", Policy, Planning and Research Working Papers Series No. 343, World Bank, Washington DC., pp. 1-41.

Engle, R.F. and Granger, C.W.J. (1987), "Co-integration and error correction: representation, estimation and testing”, Econometrica, Vol. 55, pp. 251-276.

Fambon, S., Baye, F.M., Noumbar, I., Tamba, I. and Amin, A.A. (2004), "Dynamique de la Pauvreté et de la Répartition des Revenus au Cameroun Durant les Années 80 et 90", Collaborative Final Report, AERC, Nairobi, Kenya.

Fischer, K.W. (1983), "Illuminating the processes of moral development: a commentary", Monographs of the Society for Research in Child Development, Vol. 48, pp. 97-107.

Fischer, S. (1992), "Macroeconomic stability and growth", Cuadernos de Economia, Vol. 29 No. 87, pp. 171-186.

Frankel, M. (1962), "The production function in allocation and growth: a synthesis", The American Economic Review, Vol. 52 No. 5, pp. 996-1022.

Grossman, G.M. and Helpman, E. (1991), "Quality ladders in the theory of growth", The Review of Economic Studies, Vol. 58 No. 1, pp. 43-61.

Grossman, G.M. and Helpman, E. (1992), "Innovation and growth in the global economy", International Journal of Industrial Organization, Vol. 10 No. 2, pp. 323-324.

Gujarati, D.N. (2003), Basic Econometrics, 4th ed., McGraw-Hill/Irwin, New York, NY.

Gujarati, D.N. (2004), Basic Econometrics, 4th ed., McGraw-Hill Companies, New York.

Heshmati, A., Maasoumi, E. and Wan, G. (Eds), (2015), Poverty Reduction Policies and Practices in Developing Asia, Springer, Singapore.

Islam, N. (1995), "Growth Empirics: a panel data approach", The Quarterly Journal of Economics, Vol. 110 No. 4, pp. 1127-1170.

Ismaila, M. and Imoughele, L.E. (2015), "Macroeconomic determinants of economic growth in Nigeria: a Co-integration approach", International Journal of Academic Research in Economic and Management Science, Vol. 4, pp. 34-46.

Johansen and Juselius (1990), "Maximum likelihood estimation and inference on cointegration with applications to the demand for money", Oxfrod Bulletin of Economics and Statistics, Vol. 52 No. 2, pp. 0305-9049.

Johnson, O.E.G. (2016), Economic Diversification and Growth in Africa: Critical Policy Making Issues, Palgrave Macmillan, London.

Kim, T.Y. and Heshmati, A. (2014), Economic Growth: the New Perspectives for Theory and Policy, Springer, Singapore.

Knight, M., Loayza, N. and Villanueva, D. (1993), "Testing the neoclassical theory of economic growth: a panel data approach”, Staff Papers (International Monetary Fund), Vol. 40 No. 3, pp. 512-541.
Economic growth in Cameroon

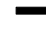


Lucas, R.E., Jr (1988), "On the mechanics of economic development”, Journal of Monetary Economics, Vol. 22, pp. 3-42.

Mankiw, N.G., Romer, D. and Weil, D.N. (1992), "A contribution to the empirics of economic growth", Quarterly Journal of Economics, Vol. 107 No. 2, pp. 407-437.

McKinnon, R.I. (1973), Money and Capital in Economic Development, The Brookings Institution, Washington, DC.

Molua, E. (2010), Assessment of Trade Facilitation and Competitiveness of Cameroon's Coffee Sector: Implications for Trade Liberalization, Department of Economics and Management, University, Buea, Cameroon.

Mundell, R. (1963), "Inflation and real interest rate", Journal of Political Economy, Vol. 71 No. 3, pp. 280-283.

Ndambiri, H.K., Ritho, C., Ng'ang'a, S.I., Kubowon, P.C., Mairura, F.C., Nyangweso, P.M., Muiruri, E.M. and Cherotwe, F.H. (2012), Determinants of Economic Growth in SubSaharan Africa: A Panel Data Approach, Center for Envirnmental Economics and policy in Africa, Pretoria.

Njinkeu, D., Kobou, G. and Noumba, I. (1997), Structural Adjustment and Poverty in CAMEROON: A Labour Market Analysis, ICEG Final Report, AERC, Nairobi.

Pesaran, M.H. and Shin, Y. (1999), "An autoregressive distributed lag modeling approach to cointegration analysis", in Strom, S. (ed.), Econometrics and Economic Theory in the 20th Century: the Ragnar Frisch Centennial Symposium, Cambridge University Press.

Pesaran, M.H., Shin, Y. and Smith, R.J. (2001), "Bound testing approaches to the analysis of level relationship", Journal of Applied Economics, No. 16, pp. 289-326.

Phillips, P.C.B. and Perron, P. (1988), "Testing for a unit root in time series regression”, Biometrica, Vol. 75, pp. 335-346.

Phiri, A. (2013), Inflation and Economic Growth in Zambia: A Threshold Autoregressive (TAR) Econometric Approach, The Bank of Zambia (BOZ) Reader, Vol. 1 No. 8, pp. 100-104.

Pindyck, R.S. and Somalino, A. (1993), "Economic stability and aggregate investment", NBER Macroeconomics Annual, Vol. 8, pp. 259-318, Répartition des Revenues au Cameroun Durant les Années 80 et 90. Final Report, Nairobi, Kenya: AERC.

Robson and Lury (2011), "Making and measuring value comparison, singularity and agency in brand valuation practice", Journal of Cultural Economy, No. 4, pp. 439-445.

Sala-i-Martin, X., Doppelhofer, G. and Miller, R.I. (2004), "Determinants of long-term growth: a bayesian averaging of classical estimates (BACE) approach", American Economic Review, Vol. 94 No. 4, pp. 813-835.

Shaw, E.S. (1973), Financial Deepening in Economic Development, Oxford University Press, New York, NY.

Shrestha and Chowdhury (2007), "Impact of financial liberalization on welfare: evidence from Nepal", Applied Econometrics and International Development, Vol. 7 No. 1, p. 14.

Solow, R.M. (1956), "A contribution to the theory of economic growth”, Oxford Review of Economic Policy, Vol. 23 No. 1, pp. 3-14.

Tambi, E. (1984), Agricultural Development Policy and Performance in Cameroon. 1960-1980, PhD Thesis, University of Pittsburgh.

Tambi, D. (2012), "The decomposition of poverty: a distributive approach to living standards", Russian Journal of Agricultural and Socio-Economic Sciences, Vol. 4 No. 4, pp. 1-11.

Ullah and Fand Rauf, A. (2013), "Impacts of macroeconomic variables on economic growth: a panel data analysis of selected asian countries", GE-international Journal of Engineering Research, available at: www.gejournal.net.

Uniamikogbo, S.O. and Enoma, A.I. (2001), "The impact of monetary policy on manufacturing sector in Nigeria”, The Nigeria Economic and Financial Review, Vol. 3 No. 2, pp. 37-45. 
Walters (1966), The Impact of Changes in Money Supply on the Value of Gross National Product (GDP) in UK, International Financial Statistics, Washington DC, pp. 107-166.

World Bank (1990), Adjustment Lending Policies for Sustainable Growth. Policy and Research Series, World Bank, Washington DC..

Economic growth in Cameroon

Zafar, I. and Zahid, G. (2013), "Macroeconomic determinants of economic growth in Pakistan", The Pakistan Development Review, Vol. 37 No. 2, pp. 125-148.

\section{Further reading}

P., M. and Cherotwe, F.H. (2012), Determinants of Economic Growth in Sub Saharan Africa: A Panel Data Approach, Center for Envirnmental Economics and policy in Africa, Pretoria.

Phillips, P.C.B. and Park, J.Y. (1988), "Statistical inference in regressions with integrated processes", Econometric Theory, Vol. 4 Part 1, pp. 468-497.

\section{Corresponding author}

Kesuh Jude Thaddeus can be contacted at: kesuhjude1@gmail.com

For instructions on how to order reprints of this article, please visit our website:

www.emeraldgrouppublishing.com/licensing/reprints.htm

Or contact us for further details: permissions@emeraldinsight.com 